\title{
An ethical dilemma in psychotherapy
}

\author{
Jeremy Holmes, Gwen Adshead and Jeanette Smith
}

\begin{abstract}
This paper examines the ethical principles of justice and autonomy in psychotherapy. A case history is presented which illustrates how ethical dilemmas concerning the type of psychotherapy to be offered are powertully influenced by often unconscious countertransference feellings in the resource allocators. The question of how autonomous a psychotherapy patient can be, when unconscious moltvations could be affecting rational choice, is also explored and possible answers provided.
\end{abstract}

The prevailing paradigm in contemporary medical ethics is the 'four principles' or 'Georgetown mantra' - beneficence, non-maleficence, respect for autonomy, and justice - first proposed by Beauchamp \& Childress (1989) and promulgated by Gillon (1985; 1993). However, the four principles approach has been criticised for failing to take account of the narrative as opposed to the philosophical texture of clinical reality (Brody, 1993) which means that for many clinicians ethical 'dilemmas' have an artificial flavour, being either "obvious or impossible to agree" (Armstrong \& Humphrey, 1993).

Further, Fulford (1989; Fulford \& Hope 1993) has argued that medical ethics tend to assume a value free medical model of practice that yields rather poor results when applied to psychiatry, whose constructs themselves imply moral issues needing clarification and debate. This is nowhere more true than in the field of psychotherapy (Holmes \& Lindley, 1989).

In this brief article, a relatively neglected area based on the fourth of the 'principles', justice, will be considered. Psychotherapists, like most other healthcare professionals, have to make decisions about resource allocations and this introduces the issue of justice, i.e. justice as 'fairness', the fair and equal opportunity to access resources, and fair and equal distribution of these. Such decisions are likely to be influenced by a number of factors including the practitioners' own therapeutic experience and their own views about the efficacy of psychotherapeutic treatments. The present case illustrates how ethical stances and unconscious processes also affect this decision which may compete or complement one another.

\section{Case history (by Jeremy Holmes)}

David was a 35-year-old teacher who was admitted to hospital having become severely suicidal and drinking heavily. The precipitant was the break-up of a two year relationship with his girlfriend, when she informed him that while on holiday she had slept with another man. David was the only son of his mother's second marriage, with an older half sister ten years his senior. He had seen little of his father, a soldier, during his childhood, although he remembered him as a disciplinarian. He left when David was 12, and he had not seen him since. After her abandonment, David's mother became depressed and dependent on her son, who felt that he sacrificed much of his independence in looking after her emotional needs. He eventually broke away and started training as a teacher in his mid-20s. While at teacher training college he wrote a long letter to his mother expressing rage about how he felt she had manipulated him. Soon after this, she developed Alzheimer's disease and went to live in an old people's home. David visited her once, was intensely distressed and guilty by her failure to recognise him, and broke off all contact with both her and his elder sister.

While in hospital David arranged to retire on medical grounds and requested psychotherapy to help deal with his still bruised feelings about the relationship and his fear of returning to an empty life and his suicidal feelings. At the psychotherapy intake committee, there was fierce debate about what form of therapy would be most suitable. One view held was that he was a severely damaged individual for whom nothing less than intense and prolonged therapy would suffice. Others argued that he was so damaged that brief supportive treatment was more appropriate, since it would be less likely to reawaken the bleak and suicidal feelings which had precipitated his breakdown in the first place. The 
battle raged, but eventually the fact that a brief therapy vacancy existed, whereas David would have to wait for several months for a long term vacancy, decided the matter.

David was offered a brief analytic therapy contract of 16 sessions. The early sessions were rather stilted with David adopting a deferential and slightly ingratiating attitude towards the therapist, possibly paralleling his relationship with his mother after his father had left. There were three main turning points in the course of the therapy. The first was when David said how inhibiting he found it that the therapist was taking notes during the session. This act of assertion seemed to give David more freedom in the sessions and helped him to feel less intimidated by the therapist, who up to then he had likened to his headmaster. The second occurred around a disagreement which broke out between David and the therapist about his relationship to his childhood. David was reluctant to explore his unhappy childhood or get in touch with painful memories. Around this time, he had a motorbike accident in which a lorry had backed into him and although he had not been badly hurt, the bike was seriously damaged. This incident seemed to symbolise his vulnerability and his sense that his parents had no awareness of his needs as a child. He bought a new bike but it did not feel 'right' - he compared this to the new identity he was trying to achieve through therapy. He then conceived the idea of using the 'good' bits of the old bike on the new one, thereby building a hybrid with which he felt satisfied - a model for a better relationship to his unhappy past. Finally, as the end of therapy approached. he became depressed again and was readmitted for two weeks. During this time, the therapist, who was also his psychiatric consultant, discussed quite forcibly on the ward round the dangers of his excessive drinking. In a subsequent psychotherapy session David was able to say how angry he had felt about this 'telling off. and to compare it with his memories of his father. However, from then on he improved and after considering the possibility of entering an analytic group decided that he might try without therapeutic support. At three month follow-up he was feeling very well and had remained abstinent from alcohol.

\section{Discussion}

Three points of intersection between an ethical and psychodynamic analysis of this case are raised (see also Holmes \& Lindley, 1993).

(a) The abstract notion of the justice of prolonged $v$. brief therapy can in this case be related to the difference between the maternal and the paternal transference. and the oedipal dilemma of a mother who is one's exclusive possession (but in oneparent families like David's also one's exclusive responsibility), or who is to be shared with father and siblings. David's longing for a merged relationship with a woman was shattered when his girlfriend was unfaithful, tipping him into suicidal depression. The choice of therapy was influenced by the therapist's perception (doubtless counter-transferentially driven) of a contrast between David's fear of a regressive prolonged and possibly unresolved maternal transference, and a paternal transference which could be dealt with in brief therapy as he became more assertive and better able to express anger and yet still value his therapist.

(b) Medical ethics frequently focuses on the conflict between autonomy and beneficence. In this case, the therapist acceded to David's insistence of his autonomy his wish not to dwell too much on his unhappy past and his refusal of the offer of more prolonged therapy. However, who 'knows best?' - the all-seeing therapist who is aware of the defensiveness of David's responses or David himself, for whom coping was paramount? Perhaps David's insistence on his autonomy was an expression of his terror of identification with his mother, of her dependency and depression and of becoming, in his words. a "revolving door patient" like her.

(c) Finally, is it possible for psychotherapists to offer their patients real choices, putting the different treatment options frankly before them, thus allowing informed decisions to be made? If one believes in unconscious motivation (psychodynamics) where does this leave room for rational choice (ethics)? Can one give informed consent to transference?

\section{Conclusion}

In this case, as probably in most ethical dilemmas, practical considerations decided the outcome. David wanted brief therapy; a vacancy was available. Justice was probably done. The basis of this seemed to be the match between David's felt needs, however 'defensive', and the philosophy and capacity of the psychotherapy service which was treating him. Echoing Marx. Armstrong \& Humphrey (1993) state mockingly that "the function of medical ethics is neither to change nor study the world, but to reveal it as a spectacle". But spectacles are not to be underestimated. Ethical analysis, like psychodynamics, can enable one to see more deeply into 
reality, a necessary preliminary to trying to change it.

\section{Commentary (by Adshead and Smith)}

Central to this case is the issue of whether patients in the psychotherapeutic relationship are autonomous. It is our opinion that such patients are autonomous and must take the lead in determining their treatment, as they are emotionally and intellectually competent for the task in hand, i.e. having therapy with a therapist. The argument about autonomy and beneficence in psychotherapy, as in the rest of psychiatry, hinges crucially on competence. We know that the definition of competence is problematic, as it is action specific, probably affected by the observer and is not a binary concept. Nevertheless it would seem very strong not to call David competent: his decision not to undertake painful reflection may be unwise but surely is not incompetent.

There are many ways to conceptualise justice which are relevant to psychiatry (Gillon, 1985) but in the case described here, justice refers to resource allocation. It is interesting how in the present case the intake panel's (i.e. the resource allocators') counter-transference, which reflected the patient's own family experiences, led them to opt for the decision that gave David less and other future patients more. The justice of this decision therefore, may have rested on unconscious feelings in the resource allocators.
We believe that ethical decisions in psychiatry are commonly influenced by often unconscious counter-transference feelings and that these issues can have a very powerful impact on clinical care and service delivery in general.

\section{References}

ARMSTRONG, D. \& HUMPHREY, C. (1993) Health care, sociology, and medical ethics. In Princtples of Health Care Ethics (ed. R. Gillon). Chichester: Wiley.

Beauchamp, T. \& Chmdress, J. (1989) Principles of Biomedical Ethics, Oxford: Oxford University Press.

BRODY, H. (1993) The Four Principles and Narrative Ethics. In Gillon (1993) op cit.

FULFORD, K.W. (1989) Moral Theory and Medical Practice. Cambridge: Cambridge University Press.

FULFORD, K.W. \& HOPE, T. (1993) Psychiatric ethics: a bioethical ugly duckling? In Principles of Health Care Ethics (ed. R. Gillon). Chichester: Wiley.

GuLON, R. (1985) Philosophical Medical Ethics. Chichester: Wiley.

- (1993) (ed.) Principles of Health Care Ethics, Chichester: Wiley.

Holmes, J. \& LINDLEY, R. (1989) The Values of Psychotherapy. Oxford: Oxford University Press.

- \& - Ethics and psychotherapy. In Gillon (1993) op cit.

Jeremy Holmes, Consultant Psychiatrist/ Psychotherapist, North Devon District Hospital, Raleigh Park, Barnstaple, Devon EX31 4JB; Gwen Adshead, Lecturer, Department of Forensic Psychiatry, Institute of Psychiatry, De Crespigny Park, London SE5 8AF; and Jeanette Smith, Sentor Registrar, Fromestde Clinic, Blackberry Hill, Bristol BS16 1EP 